\title{
MODELING WORD ORDER VARIATION IN DISCOURSE: ON THE PRAGMATIC PROPERTIES OF VS ORDER IN OLD HIGH GERMAN
}

\author{
SVETLANA PETROVA \\ Humboldt-Universität zu Berlin
}

\section{AB S T R AC T}

In Old High German, verb-initial matrix declarative clauses display a variety of functions which are broadly related to discourse structure. However, the thoV2 construction also correlates with the factors triggering verb-initial placement. The paper shows that the preference of the one pattern over the other cannot be explained in terms of a single, straightforward criterion. Rather, several factors influencing the choice process have to be distinguished. The paper tests the effect of these factors by using methods and tools developed to capture variability in sociolinguistics.

\section{[1] INTRODUCTION}

The present paper examines the factors that govern the selection of two functionally related word order patterns in matrix declarative clauses in Old High German (henceforth $\mathrm{OHG}$ ). Both patterns display a post-verbal subject in the surface, i.e. VS order. In the first case, the inflected verb is in clause-initial position, preceding all remaining constituents (henceforth V1). In the second one, the sentence particle or adverb tho (spelled also thô and thó in the manuscripts) 'then' is placed clauseinitially, followed by the inflected verb in second position. This word order pattern will be referred to as tho-V2. The obligatory inversion of the subject and the subsequent second position of the inflected verb, immediately after the clause-initial tho, are commonly assumed to result from the verb-second constraint typical of modern German and obviously established already in the earliest attested periods of the language (cf. Axel 2007).

Research interested in the role of information structure in word order variation in OHG has recognized that the functions of the patterns described above are to a high extent equivalent, and that they in a similar way contribute to grounding and cohesion in discourse (Betten 1987; Petrova \& Solf 2008; Hinterhölzl \& Petrova 2011). More precisely, both patterns are used to indicate temporal succession of events and

[1] This is the cognate of OE $p a$ which also regularly triggers subject-verb inversion in OE (cf. Kemenade 1987; Fuss 2003; Fuss \& Trips 2009). 
progress in narration. A more recent investigation by Donhauser \& Petrova (2009), however, shifted the attention to a variety of conditions that seem to favor the use of the one pattern over the other. They observe that the two patterns function differently if we take into consideration the lexical class of the verb, the fine structure of the discourse, and the temporal properties of tho.

The main issue of the present study is to examine the interaction of these conditions by using software developed to model variability in language. Data showing variation of the two patterns in $\mathrm{OHG}$ are analyzed with respect to various relevant factors described in the previous literature. After that, the results of a variable rule analysis are presented that has been conducted by using Goldvarb X (Sankoff \& Tagliamonte 2005), which is an established tool for modeling variability in sociolinguistics.

\section{[2] REMARKS ON THE CORPUS}

OHG (c. 750-1050) is attested in a variety of vernacular translations from Latin and in heroic or religious poems. At the same time, no authentic prose texts from this period are handed down to us, which makes research on word order more than problematic (Fleischer 2006). In what is available, we have to assume that the attested word order patterns and constructions are not representative of native $\mathrm{OHG}$ grammar but rather influenced by the syntax of the Latin original or by metrical considerations.

A number of authors, however, e.g. Ruhfus (1897), Donhauser (1998), Dittmer \& Dittmer (1998) have proposed a solution to this data problem. They have assumed that $\mathrm{OHG}$ translations provide native evidence in those cases where the vernacular text changes the constituent order of the corresponding Latin clause. Taking this restriction as a starting point, we can obtain the largest corpus of potential native structures by analyzing the OHG Tatian translation (St. Gallen Cod. 56), which provides 340 folia of bilingually attested material, thus allowing a systematic comparison of the Latin original and the OHG translation. The text is dated back to the middle of the 9th century. A number of recent philological investigations have provided important insights into the translation technique implemented in this codex and have emphasized the high value of this record for investigations on OHG word order (Masser 1997; Fleischer et al. 2008).

Project B4 of the Collaborative Research Center on Information Structure at the Humboldt University Berlin ${ }^{2}$ has provided a database of clauses differing from the word order of the Latin structure in a relevant part of the Tatian codex (on the design and annotation principles of this corpus, cf. Petrova et al. 2009). For the purpose of this study, I extracted from this database all declarative clauses which display the two patterns to be discussed in this paper. Concerning V1 declaratives, I con-

[2] http://www2.hu-berlin.de/sprachgeschichte/forschung/informationsstruktur/index. php. 
centrated on examples containing the adverb tho in clause-internal position, as a systematic comparison of the properties of post-verbal tho with those of pre-verbal tho in the tho-V2 construction will become relevant for the analysis. Also among the group of verb-initial declaratives, I ignored coordinate non-initial conjuncts in which the verb is in first position due to ellipsis of the subject. Similarly, potential cases of topic-drop leading to superficial V1 have been left out of consideration. All examples are cited by manuscript page and line number according the text edition by Masser (1994).

\section{[3] THE FUNCTIONS OF VS ORDER IN OHG}

\section{[3.1] Previous accounts on verb-initial declaratives in $\mathrm{OHG}$}

Recent generative work on the structure of the left periphery in OHG analyzed verbinitial declaratives as matrix clauses in which the finite verb moves to $\mathrm{C}^{0}$ but Spec,CP (traditionally called the prefield of the clause) remains empty (Axel 2007). Evidence for verb fronting to $C$ is provided by the fact that the inflected verb appears to the left of elements that mark the right and left edge of the VP in asymmetric SOV/V2 languages like modern German. Take, e.g., verbal particles which in basic order immediately precede the verb (1) but which are regularly stranded in root contexts (2a). Additionally, we can observe that the verb appears above pronouns and light adverbs in root clauses. Under the assumption that these elements occupy the socalled Wackernagel domain, i.e. the left edge of the middlefield, immediately below $\mathrm{C}^{0}$, we may conclude that verb fronting in root clauses targets a position in the $\mathrm{C}$ domain of the clause, as represented in (2b). At the same time, no XP-movement to $\mathrm{Spec}, \mathrm{CP}$ takes place in these cases, suggesting that filling of the prefield in matrix declaratives was still optional in OHG:

$$
\begin{aligned}
& \text { mit thiu her uzgieng zí erdu } \\
& \text { when he out-PRT-go-3sG.PRET to land-DAT.sG } \\
& \text { 'when he went out to the shore' } \\
& \text { Lat. \& cum egressus ess\& ad terram }
\end{aligned}
$$
a. árstuont siu tho úf rise-3SG.PRET she then-PRT UP-PRT 'She arose then' Lat. \& surrexit
b. [CP C árstuont $\mathrm{i}_{\mathrm{i}}\left[\mathrm{VP}\right.$ siu tho úf $\left.\left.\mathrm{t}_{\mathrm{i}}\right]\right]$

This situation allows for some important conclusions concerning the development of V2 in German. A notable observation is that the generalization of the different components of the verb-second rule, i.e. verb fronting to $C$ and XP-movement to $\mathrm{Spec}, \mathrm{CP}$, does not occur simultaneously but rather proceeds successively, in a gradual fashion. In view of the facts presented above we can hypothesize that in the 
classical OHG period, verb fronting is already firmly established, while XP-movement to the prefield is obviously not obligatory yet. Note that merging of expletive 'es' as a basic property of the V2 rule has not emerged yet in OHG but is attested towards the Middle High German period (Axel 2007). From the analysis of V1 declaratives, we can obtain insight into the factors that prevent movement to Spec, $\mathrm{CP}$ in the historical stages of German.

Numerous facts on the distribution of V1 declaratives in OHG are provided in traditional historical descriptions of German word order, e.g. Braune (1894), Ruhfus (1897), Diels (1906), Maurer (1924) and Behaghel (1932). The authors report on a multitude of functions of V1 clauses, pointing out a number of heterogeneous syntactic, semantic and discourse-related factors which correlate with verb-initial order in matrix declaratives in OHG. First, they recognize that V1 is preferred with a number of semantically non-related classes of predicates, such as existential 'be', verbs of motion, verbs of saying before citation, impersonal predicates, etc. Second, V1 is identified as a typical text-opening strategy, also regularly applied at episode onsets within a text. Additionally, the authors relate V1 to various effects of foregrounding, expressivity and unexpectedness.

In the more recent literature, there have been attempts at explaining the functions of verb-initial declaratives in OHG in terms of one single, very general criterion. As will become clear from the overview, none of them provides a satisfactory explanation of $\mathrm{V} 1$ in $\mathrm{OHG}$.

Hypothesis 1: Verb-initial order as a non-native pattern signalling foreign speech Robinson (1994) examines verb-initial declaratives in the OHG Isidor translation (c. 800). His comparison of V1 clauses in the OHG text with their Latin counterpart shows that independent evidence for matrix V1-order is rare in the Isidor text. Furthermore, Robinson discovers that Latin V1 is retained in biblical citations more often than in explanatory parts of the treatise. From this he concludes that V1 is a non-native pattern used in the translation of biblical citations as a signal of foreign speech.

Robinson's explanation is untenable with respect to the following counterarguments. First, as already outlined above, we find V1 in matrix clauses which deviate from the word order of the Latin original and must therefore be considered a genuine OHG pattern, cf. (3). Second, V1 is attested in the remaining early Germanic languages as well. It is a well-know property of old Norse prose syntax, documented in various grammar books (e.g. Nygaard 1966, § 228; Heusler 1977, § 508) and studied extensively in the literature (Sigurðsson 1990; Leiss 2000 among others). But also in the Germanic records that are closer to the time of the OHG period ${ }^{3}$ do we find evidence for V1 in matrix declarative clauses, e.g. in Old English (OE) (Pintzuk 1996,

[3] Recall that Old Norse prose is attested from the 12th century on, cf. Ranke \& Hofmann $(1988,13-18)$. 
379 ) and Old Saxon (OS) (Linde 2009). Below, I provide examples from the OE Blickling Homilies (Morris 1967), cf. (4), and from the OS Heliand (Sievers 1935), (5):

(3) giengung thô zuo gotes engila go-3PL.PRET then-PRT to-PRT Lord-GEN.SG angel-NOM.PL 'The angels of the Lord appeared' Lat. Et ecce angeli accesserunt

(4) Secgge ic pe nu eac say-1sG.PRES I you-DAT.SG now also 'now I also tell you'

(BlickHom 201)

(5) Lag thar ên felis bioban lay-3SG.PRET there a stone upon 'there was a stone upon' (Heliand 4075)

It is justified to assume, then, that V1 represents a common Germanic pattern in matrix declarative clauses.

Hypothesis 2: Verb-initial order in clauses with no thematic material

Lenerz (1984) proposed an account according to which V1 in OHG is typical for presentational constructions which are fully rhematic, i.e. which convey no thematic information suitable to be placed pre-verbally in the clause (cf. also Ramers 2005). However, we can provide counterevidence against such a view. First, verb-initial declaratives with existential 'be' can also contain given information, e.g. in thero landskeffi 'in that region' in (6), while novel information is conveyed in the subject expression hirta 'shepherds' only. Moreover, apart from presentational sentences and existential constructions, we encounter evidence for verb-initial declaratives whose subjects are pronouns (7) or anaphoric DPs (8):

(6) uuarun thô hirta In thero landskeffi be-3PL.PRET then-PRT shepherd-NOM.PL in DEM.DAT.SG.FEM region 'There were shepherds in that region'

Lat. Et pastores erant In regione eadem

(7) quamun sie thó come-3PL.PRET they then-PRT

'Then they came'

Lat. \& uenerunt 


(8) uuard tho giheilit ther kneht in
PASSAUX.3SG.PRET then-PRT heal-PAST.PART DET.NOM.SG boy in
thero ziti
DET.DAT.SG.FEM moment-DAT.SG
'And the boy was healed in this very moment'
Lat. \& sanatus est puer in illa hora

$(\mathrm{T} 84,7)$

This means that we are in need of an explanation of V1-order in declaratives that is able to account for subject-verb inversion with both given and novel subjects in the clause.

Hypothesis 3: Verb-initial order with unaccusative verbs

According to the third hypothesis, VS-orders in general, and V1 order in Germanic in particular, are typical for intransitive unaccusative verbs whose subjects are underlying objects, thus realized in the canonical post-verbal object position in the surface, cf. Lenerz (1992). However, our database provides examples of verb-initial declaratives with transitive verbs selecting accusative objects as in (9a)-(9b):
a. Intfiengun sie tho
thes
heilantes
receive-3PL.PRET they then-PRT DET.GEN.SG Saviour-GEN.SG body
'They took then the body of the Saviour'
Lat. Acceperunt autem corpus ihesu
b. Quad her tho zi then giladoten /
tell-3SG.PRET he then-PRT to DET.DAT.PL invited-DAT.PL
ratissa
parable-ACC.SG
'He told to the invited people the following parable'
Lat. Dicebat autem \& ad Inuitatos / parabolam

lichamon

This suggests that transitive verbs are equally possible in clause-initial position in OHG.

Hypothesis 4: V1 and narrative inversion in Germanic

In the context of the remaining Germanic languages, V1 declaratives are related to the notion NARRATIVE INVERSION. It has been claimed by Santorini (1989) for Yiddish and Sigurðsson (1990) for Icelandic that V1 in declarative clauses implies a close relation to the previous statement. Therefore, V1 declaratives are said to be restricted to discourse continuative contexts and to be excluded from discourseinitial ones. But this account is untenable for the early Germanic languages on empirical grounds. In Petrova (2006) it has been shown that V1 declaratives are regularly used to introduce new discourse units not only in OHG but also in OE and OS. Furthermore, clause-initial placement of the inflected verb regularly corresponds 
to graphical means of marking episode boundaries like capital initials, chapter numbers or marginal notes, as shown for the OHG Tatian text in Figure 1 on page 224.

\section{[3.2] A discourse-based approach to VS order in $\mathrm{OHG}$}

Hinterhölzl \& Petrova $(2010,2011)$ present a discourse-based approach aiming at a unified explanation of verb-initial declaratives in OHG. Their argumentation goes as follows: As also pointed out in the previous literature, V1 systematically appears in presentational clauses and existential constructions. The basic function of these constructions is to introduce NEW REFERENTs to the discourse. In theoretical terms, such types of clauses are subject to a further specification with respect to information structure, namely, they lack a topic-comment structure (Drubig 1992; Sasse 1995). Rather, the entire clause is in the scope of assertion, or in focus. Likewise, the remaining types of verb-initial declaratives can be unified under the property of triggering wide-scope assertion and no topic-comment division. This interpretation is prompted by the lexical semantics of the predicates as well as by the property of V1 clauses to appear discourse-initially. Motion verbs, verbs of saying before citation, phase verbs and transformative/inchoative predicates, as well as discourseinitial contexts are equally incompatible with the type of discourse linking that Asher \& Lascarides (2003) call ELABORATION. Rather, clauses with these properties assert a NEW STATE OF AFFAIRS, or the initiation of a new phase in the discourse. In other words, these types of $\mathrm{V} 1$ declaratives are used to introduce a new situation to the discourse.

However, the functions described for verb-initial declaratives in $\mathrm{OHG}$ are also common to another, very frequently attested pattern, namely to the tho-V2 construction. It can be seen from the examples below that this pattern also occurs with existential 'be' (10), as well as with the verb classes described for V1. I present examples of motion verbs (11), verbs of saying before citation (12), and a transformative predicate (13):

(10) tho uuas man In hierusalem

then-PRT be-3SG.PRET man in Jerusalem

'There was a man in Jerusalem'

Lat. homo erat In hierusalem

(11) thó giengun scalca zuo / thes híuuiskes

then-PRT go-3PL.PRET slave-NOM.PL to-PRT DET.GEN.SG family-GEN.SG

fater

father

'Then, the slaves of the father of the family came'

Lat. accedentes serui / patris familias autem

(T 108,28-29) 
(12)

thô quad maria

then-PRT say-3sG.PRET Mary

'Then, Mary said'

Lat. Dixit autem maria

thó uuvrdun sie gifulte alle / in theru

then-PRT PASSAUX.3PL.PRET they fill-PAST.PART.PL all in DET.DAT.SG

samanungu gibuluhti

synagogue anger-DAT.SG

'Then, all in the synagogue became filled with anger'

Lat. \& repleti sunt omnes / in sinagoga ira

Wide-scope assertion, and the lack of topic-comment structure can therefore be identified as the common function of VS order in both V1 and tho-V2 declaratives in OHG. This, in turn, implies that we encounter variation between two syntactic patterns used to express non-elaborative relations between utterances in coherent discourse in OHG.

In the remainder of this paper, I will address how to assess this variation by identifying and testing the influence of different factors and their combinations on the choice between V1 and tho-V2 in declarative clauses in OHG.

\section{[4] FACtoRs influencing THE CHOICE BETWEEN V1 AND THO-V2}

\section{[4.1] Argument structure}

VS order in general, and verb-initial declaratives in particular, are a pertinent object of investigation not only in diachronic linguistics but in contemporary typological studies as well. The results of a recent exhaustive examination of VS order in a variety of Indo-European and non-Indo-European languages are summarized in Sasse (1995). Here, an important distinction is made between VS orders proper, and cases in which the clause-initial placement of a particular constituent obligatorily triggers inversion of the subject. These two sub-classes are therefore comparable to the patterns examined for OHG in this study.

One of the factors that according to Sasse (1995) favors the use of VS constructions from a typological perspective is MONOARGUMENTALITY. This is a cover term used for a number of formally heterogeneous constellations in which the predicate selects only one nominal argument. Next to strict intransitives, the class of monoargumental predicates also includes passive and medio-passive constructions, reflexives as well as predicates which select a clausal argument.

Predicates of this kind constitute the major part of the evidence for V1 declaratives in the OHG corpus. Data for V1 order with strict intransitives and with passives were given in (3), (6), (7) and (8) above. Here, I provide examples of V1 with reflexives (14) as well as with matrix verbs selecting clausal arguments (15): 
(14) gioffonota sih thô sliumo sîn mund

open-3SG.PRET REFL then-PRT suddenly his mouth

'His mouth was opened suddenly'

Lat. apertum est autem ilico ós eius

(15) gisahun tho thie buohhara inti pharisei / thaz her see-3PL.PRET then-PRT DET Scribe-NOM.PL and Pharisee-NOM.PL that he áz mit then suntigon eat-3SG.PRET with DET.DAT.PL sinful-DAT.PL

'the scribes and the Pharisees saw that he had supper with the sinful people' Lat. \& uidentes scribe \& pharisei...

(T 91,13-14)

Therefore, we will examine the relevance of the factor MONOARGUMENTALITY for the choice between V1 and tho-V2 in the data.

\section{[4.2] Lexical semantics}

Sasse (1995) outlines a number of LEXICAL CLASSES OF PREDICATES reported to correlate with VS order cross-linguistically. Among these are existential verbs, verbs denoting the appearance/disappearance of a referent, psych-verbs, ${ }^{4}$ verbs of utterance/emotions, etc. OHG is completely consistent with the situation found crosslinguistically. I already provided examples of clauses with existential 'be' in (6) and of verbs denoting the appearance of a referent (cf. (3) and (7) above). Apart from this, $\mathrm{V} 1$ is also attested in $\mathrm{OHG}$ in clauses denoting the withdrawal of a referent from the scene, cf. (16). Finally, verb-initial order is regularly found with psych-verbs (17) as well as with verbs of utterance (18):

(16) arfuor tho / fon Iru ther engil depart-3SG.PRET then-PRT from she-DAT.SG.FEM DET angel 'the angel left her'

Lat. \& decessit / ab illa angelus

uuard thô forhta ubar alle Iro nahiston

become-3SG.PRET then-PRT fear above all her-DAT.PL relative-DAT.PL

'all her relatives were caught by fear'

Lat. \& factus est timor super omnes uicinos eorum

(18) quad her thô

say-3SG.PRET he then-PRT

'then he said'

Lat. ait

A further remarkable property of the predicates triggering VS cross-linguistically is

[4] Psych(ological) verbs are a class of predicates whose argument structure involves an Expriencer as a subject, like like, hate, worry/become worried or fear. 
that they do not form a natural class but are semantically heterogeneous. As Sasse points out, in none of the languages examined is "VS [...] explicitly confined to or automatically triggered by a well-defined homogeneous semantic class of predicates" 1995, 23. OHG is obviously no exception in this respect. However, Donhauser \& Petrova (2009) observe a peculiar mismatch between the frequencies with which the different classes of VS-triggering predicates appear in the V1 and the tho-V2 construction in OHG. Whereas V1 seems to impose no restrictions on the lexical class of the predicate, tho-V2 appears to be especially frequent with verbs of saying before citation. Therefore, the lexical class of the predicate is an important feature to be tested in relation to the choice between V1 and tho-V2 in OHG.

\section{[4.3] Aktionsart}

A further semantic factor reported to correlate with verb-initial order in modern languages allowing VS is related to aspectuality, more precisely to the AKTIONSART of the predicate. Sornicola (1995) reports that matrix verbs containing one of the features [+Ingressive], [+Punctual], [+Resultative] strongly favor VS order in Spanish and Italian.

In the literature on early Germanic, it has often been assumed that there is a close relation between the aspectual semantics of the verb and its position in the clause (see Hopper 1979 on OE). In its most explicit form, this hypothesis is advocated by Leiss (2000), who claims that clause-initial verb placement is a perfectivization strategy in Old Norse. It is hard to generalize this function for all cases involving a clause-initial verb in OHG, e.g. for existential 'be'. But apart from this, it is obvious that verbs in clause-initial position often display the prefix gi- (19), which is considered an overt marker of perfectivity in OHG (cf. Schrodt 2004, 2-4). Furthermore, we find in clause-initial position verbs that are inherently perfective (20) as well as the verb beginnan 'to begin' (21) including related verbs expressing the initiation of a new state of affairs. It is especially revealing that verbs which are standardly used in a stative/durative meaning like gilouban 'to believe ${ }^{5}$ in (22) receive an inchoative reading if used clause-initially. In the translation of (22), the context requires the use of additional lexical means of enforcing the interpretation that the utterance is not about a general attitude of the disciples to Jesus but about a single occasion in which they became convinced by his words:

$$
\begin{aligned}
& \text { giforhtun sie In thô In mihhilero forhtu } \\
& \text { fear-3SG.PRET they he-ACc then-PRT in great-DAT.SG fear-DAT.SG } \\
& \text { 'and they were caught by great fear' } \\
& \text { Lat. \& timuerunt timore magno }
\end{aligned}
$$

[5] Note that the prefix gi- in gilouban 'to believe' cannot be interpreted as a perfectivization marker as the compound verb is regularly attested in its usual durative meaning. 
$(20)$

uuard tho gitan / mihhil stilnessi

PASSAUX.3SG.PRET then-PRT do-PAST.PART great calm

'it [the weather] became very calm'

Lat. \& facta est / tranquilitas magna

(T 86,24-25)

(21) bigondun tho thenken / thie buohhara inti

begin-3PL.PRET then-PRT think-INF DET Scribes-NOM.PL and

pharisei

Pharisees-NOM.PL

'The scribes and the Pharisees began to think'

Lat. \& ceperunt cogitare / scribae \& pharisei

(T 89,14-15)

(22) giloubtun in inan thó sine iungiron

believe-3PL.PRET in he-ACC then-PRT his disciple-NOM.PL

'his disciples became convinced by his words/started to believe in his words'

Lat. crediderunt in eum discipuli eius \&

(T 56,10)

\section{[4.4] Temporal properties of referential tho}

Donhauser \& Petrova (2009) observe a further difference between the V1 and tho-V2 construction in $\mathrm{OHG}$ which relates to the information-structural properties of tho as a temporal adverbial. In those cases where reference to a time interval can be clearly established, the following properties of tho can be distinguished: On the one hand, tho can refer to a novel, indefinite time interval introduced as the topic time ${ }^{6}$ of a new episode. In this case, tho represents new information in the discourse. In (23), e.g., tho is identical with the temporal adjunct in anderemo sambaztag 'on another Sabbath' which establishes the topic time of a new episode. On the other hand, tho may refer to the situation time of the utterance, which is embedded in the topic time of the previous event or section. Cf. (24), in which tho refers to a time span already established in the preceding section (here, the presentation in the temple, Lk 2:21-39). Tho represents contextually given information in this case.

uuas thó giuuortan in anderemo

PASSAUX.3SG.PRET then-PRT become-PAST.PART in another-DAT.SG

sambaztag

Sabbath

'It happened on another Sabbath'

Lat. Factum est in alio sabbatum autem

(24) tho uuas man In hierusalem

then-PRT be-3SG.PRET man in Jerusalem

'A man lived in Jerusalem at that time'

Lat. homo erat in hierusalem

[6] I use the terms 'topic time' and 'situation time' in the way argued for by Klein (1994). 
According to the analysis of Donhauser \& Petrova (2009), the information-structural properties of tho correlate with its syntactic position in the clause. On a broad scale, novel tho prototypically appears post-verbally, thus giving rise to V1 in the surface, while given tho is canonically realized pre-verbally, thus leading to subject inversion in the clause.

A further sub-case has to be distinguished in which tho does not refer to the entire interval introduced in the previous discourse but rather to a section within it. In this case, tho is information-structurally accessible by virtue of the fact that it is in a part-whole relation to a previously established entity in the discourse. In most of the cases, accessible tho behaves like given tho.

Consider the small discourse in (25) which demonstrates the prototypical distribution of tho found in Tatian. The first clause opens a new episode in the story. In the Latin text, this is marked by capitalization of the initial in Et 'and' as well as by concordance notes signalling the change to another part of the New Testament (cf. Figure 1 on page 224). In this clause, tho refers to a new, indefinite time interval established as the topic time of the entire section, and follows the clause-initial verb gieng 'he went'. In the subsequent dialogue part, tho refers to the situation time of each clause, which takes successive sub-intervals of the pre-established topic time. The adverb tho is information-structurally accessible and occupies the initial position in the clause.

\#1 gieng tho zuo / ein buochari inti quad imo [...] /\#2 tho quad imo ther heilant [...] / \#3 tho quad her zi andaremo man [...]

'\#1 After that, a certain scribe came and said to Him [...] \#2 Then, the Saviour said to him [...] \#3 Then, He said to another man [...]'

Lat. \#1 Et accedens / unus scriba. ait illi [...] / \#2 \& dicit ei ihesus [...] / Ait autem ad alterum

(T $85,21-29)$

Certainly, the information-structural properties of tho are difficult to tag, in that there are instances varying between the different categories in this factor group, thus demanding the personal judgement of the annotator. Take, e.g. (14), repeated as (26), referring to the story about the Nativity of John the Baptist, namely to the event when Zacharias is given back his voice (Lk 1:59-79):

$$
\begin{aligned}
& \text { gioffonota sih thô sliumo sîn mund } \\
& \text { open-3SG.PRET REFL then-PrT suddenly his mouth } \\
& \text { 'His mouth was opened suddenly' } \\
& \text { Lat. apertum est autem ilico ós eius }
\end{aligned}
$$

On the one hand, tho can be related to the situation time in which voice is restored to Zacharias. This prompts an interpretation of tho as accessible because it is part of the previously established topic time interval. Alternatively, we can interpret 
this clause as introducing a new phase in the narrative, namely the one in which Zacharias is able to speak again. This time interval is by no means identical with the topic time of the previous part of the narrative, so novelty of tho seems justified here as well. Because of these ambiguities, the factors motivating the assignment of the category 'new' to tho should be explained in some detail.

In its most explicit form, novel tho is part of the introductory clause of a completely new story. More precisely, tho is coreferent with an overt temporal adverbial establishing a new time span as in (23), or it is interpreted as an indefinite time adjunct, as in the opening conjunct in (25). In the latter case, proper translations are 'once', 'some day' etc. But apart from this, tho can also establish the topic time of a sub-section, as in (6) above, which introduces a new sub-episode in the story about the Nativity of Christ (Lk 2:1-20), or as in (9b), where we remain within an on-going dispute between Jesus and the Pharisees, but where a new parable starts (Lk 14:7-10). Finally, tho can establish a new phase within an episode, e.g. a turning point in the narrative, which initiates a series of subsequent events. This applies to the examples in (2a), (7), (17), (20), (22) above.

At the same time, there are exceptions in which post-verbal tho is accessible (18) or given (8). Note that in the latter instance, tho quite explicitly refers to the definite interval in theru ziti 'at this very moment', which is clearly given.

\section{[5] VARIABLE RULE ANALYSIS}

I conducted a variable rule analysis using the statistics package Goldvarb X (Sankoff \& Tagliamonte 2005). I tagged for the above mentioned factors $65 \mathrm{~V} 1$ clauses with post-verbal tho and 97 tho-V2 clauses which I extracted from the Tatian database described in section [2]. I defined as a dependent variable the type of pattern involved in the clause. The factors that I distinguished within the independent variables, also called factor groups, are given in Table 1 on page 222.

The outputs that are of importance for the interpretation of the results are significance, factor weight, and step-up/step-down analysis.

Let us look at the results for significance and factor weight, cf. Table 2 on page 222. The first output shows us whether or not a factor group is statistically significant at the .05 level. It is important to know that this output applies for the entire factor group, i.e. it does not indicate which particular factor within a factor group causes the effect on the dependent variable. This is rather provided by factor weight. This output indicates the degree to which each individual factor influences the presence of the dependent variable in the data set. Factor weight is expressed as a probability between 0 and 1 for each factor within each factor group, with 0.5 and below indicating no effect on the choice process.

The results of the statistical analysis show that each factor group examined in the study has a highly significant effect on the dependent variable, i.e. all factor groups include factors that have a strong favoring effect on the choice of V1 over 


\begin{tabular}{ll}
\hline Independent factor groups & Factors \\
\hline Argument structure & $\begin{array}{l}\text { monoargumental predicates } \\
\text { non-monoargumental predicates } \\
\text { existential be } \\
\text { verbs of saying } \\
\text { motion verbs } \\
\text { rest } \\
\text { [+Ingress] [+Punct] [+Result] }\end{array}$ \\
Aktionsart & unmarked contexts \\
& new \\
Information-structural properties of tho & given \\
& accessible \\
& 11 \\
\hline
\end{tabular}

TABLE 1: Overview of independent factor groups

\begin{tabular}{llll}
\hline $\begin{array}{l}\text { Independent } \\
\text { factor groups }\end{array}$ & Significance & Factors & $\begin{array}{l}\text { Factor } \\
\text { weight }\end{array}$ \\
\hline Argument structure & $\mathrm{p}=0.001$ & monoargumental predicates & 0.596 \\
& & $\begin{array}{l}\text { non-monoargumental predicates } \\
\text { existential be }\end{array}$ & 0.404 \\
Lexical semantics & $\mathrm{p}<0.001$ & $\begin{array}{l}\text { verbs of saying } \\
\text { motion verbs }\end{array}$ & 0.889 \\
& & rest & 0.251 \\
& & [+Ingress] [+Punct] [+Result] & 0.974 \\
Aktionsart & $\mathrm{p}<0.001$ & unmarked contexts & 0.655 \\
& & new & 0.817 \\
Information-structural & $\mathrm{p}<0.001$ & given & 0.942 \\
properties of tho & & accessible & 0.299 \\
& & & 0.419 \\
\hline
\end{tabular}

TABLE 2: Results for significance and factor weight 
tho-V2 in the corpus. Let us look at the individual factor weights which the software produced for each group.

For argument structure, we have one value above 0.5. But this does not automatically indicate a strong effect of the factor on the dependent variable (cf. Tagliamonte 2006, 145). Rather, we have to compare the values obtained for all factors in the group. In this case, we can see that the values for the two factors are close to each other, and that one of them is only slightly above 0.5 . This means that although the significance of the factor group is statistically very high, the effect of the individual factors is not particularly strong on the choice of V1 over tho-V2 in the corpus.

However, within the remaining factor groups, we can isolate factors that are extremely relevant for the use of V1, and such that clearly disfavor V1. Let us look at lexical semantics first. Here, all factors except verbs of saying have a strong favoring effect on V1 in OHG, most significantly motion verbs and existential 'be'. This confirms the observation made initially by Donhauser \& Petrova (2009) that tho-V2 shows a strong preference for verbs of saying, while other predicates correlating with VS order in OHG are more or less equally represented with V1 declaratives.

Furthermore, the outputs for Aktionsart confirm that features like [+Ingressive], [+Punctual] and [+Resultative] correlate with V1 more regularly than with tho-V2. Finally, the examination of the information-structural properties of tho yields an important result for our analysis: if tho refers to a novel, indefinite time interval, then the probability to have V1 in the surface is significantly higher than with the other factors distinguished in this group.

A powerful feature of Goldvarb X is the step-up/step-down analysis which tests all possible combinations of factor groups to find out those which yield the most statistically significant results. In other words, the program identifies those combinations which allow for the most factor groups to be included while staying below $\mathrm{p}=.05$. Let us look at the output of the step-up/step-down analysis for our corpus data. The most statistically significant result $(\mathrm{p}=0.025)$ is identified for the combination of tho representing a novel time interval with a verb which is non-specified for verb class and which is unmarked for Aktionsart. This shows that not only is each factor group significant but also the combination of the three is below the threshold for statistical significance. But at the same time, it can be deduced that that novelty of tho is the factor that contributes to the statistically significant results of the step-up/step-down analysis, since given and accessible tho have low factor weights.

\section{[6] CONCLUSION}

The results of the statistical analysis confirmed the significance of the factors related to V1 in the previous literature. But now we are in a position to make more precise statements on the validity of the factors reflected before. Accordingly, while monoargumentality turns out to play a role in the selection of both patterns, prop- 
erties related to Aktionsart and information structure are very strong factors for the use of verb-initial declaratives in OHG.

The analysis also led to results concerning factors that disfavor V1 in the data set. E.g., among the lexical classes favoring VS order in OHG in general, verbs of saying are more strongly associated with tho-V2 than with V1.

Another result can be read off the variable rule analysis. It demonstrates the high significance of the information structural properties of tho for the choice of V1 in discourse: the novelty of the time interval referred to by tho triggers V1 significantly more often even in those contexts in which other relevant factors for V1 do not apply. This, in turn, is consistent with previous observations on the role of information structure for syntactic variation in the left periphery of matrix clauses in OHG. It has been shown elsewhere that with expressions referring to individuals, movement to Spec,CP in OHG is related to those phrases which show properties of canonical sentence topics, i.e. referentiality, givenness/specificity, definiteness/identifiability etc. (cf. Petrova \& Solf 2008, Hinterhölzl \& Petrova 2011). From the perspective of the present study, we can extend this generalization to expressions referring to situations: novelty and indefiniteness of the time interval referred to by the temporal adverbial tho prevent its movement to Spec, $\mathrm{CP}$, while canonical properties of topicality like reference to a contextually given and identifiable interval favor its initial positioning in the clause.

\section{AC KNOWLEDGEMENTS}

This study is part of my work in Research Group B4 "The role of information structure for the development of word order regularities in Germanic" within the Collaborative Research Centre on Information Structure at the Humboldt University Berlin. I thank two anonymous reviewers for valuable comments on an earlier version of the paper. I am also grateful to Christopher D. Sapp (Mississippi) for introducing Goldvarb to me as well as for his help in interpreting the results of the analysis. I also thank the Stiftsbibliothek St. Gallen (Switzerland) for allowing me to reproduce the illustration in the Appendix.

\section{APPENDIX}

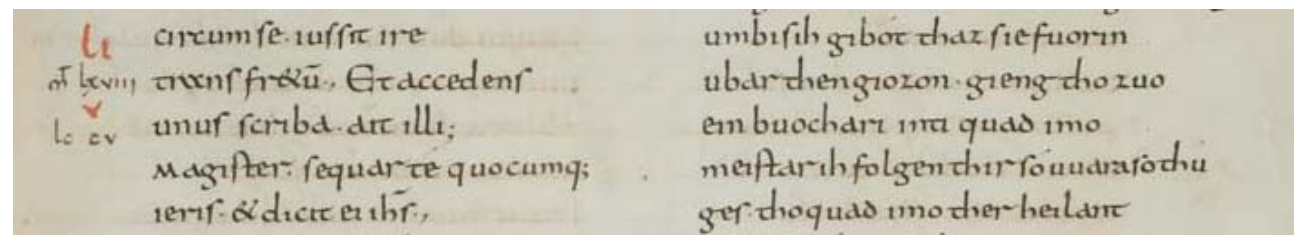

FIGURE 1: St. Gallen Cod. 56; 85, 21-24; Codices Electronici Sangallenses http:// www.e-codices.unifr.ch/fr/csg/0056/85/medium 


\section{REFERENCES}

Asher, N. \& A. Lascarides. 2003. Logics of conversation. Cambridge: Cambridge University Press.

Axel, K. 2007. Studies in Old High German Syntax: left sentence periphery, verb placement and verb-second. Amsterdam-Philadelphia: John Benjamins.

Behaghel, O. 1932. Deutsche Syntax. Eine geschichtliche Darstellung. Band IV. Periodenbau. Heidelberg: Carl Winter.

Betten, A. 1987. Zur Satzverknüpfung im althochdeutschen Tatian. Textsyntaktische Betrachtungen zum Konnektor thô und seinen lateinischen Entsprechungen. In R. Bergmann, K. Matzel \& L. Voetz (eds.), Althochdeutsch. Band 1. Grammatik. Glossen und Texte, 395-407. Heidelberg: Max Niemeyer.

Braune, W. 1894. Zur Lehre von der deutschen Wortstellung. In R. Kögel (ed.), Forschungen zur deutschen Philologie. Festgabe für Rudolf Hildebrand zum 13. März 1894, 34-51. Leipzig: Veit \& Co.

Diels, P. 1906. Die Stellung des Verbums in der älteren althochdeutschen Prosa. Berlin: Mayer \& Müller.

Dittmer, A. \& E. Dittmer. 1998. Studien zur Wortstellung-Satzgliedstellung in der althochdeutschen Tatianübersetzung. Göttingen: Vandenhoeck \& Ruprecht.

Donhauser, K. 1998. Negationssyntax im Althochdeutschen. Ein sprachhistorisches Rätsel und der Weg zu seiner Lösung. In K. Donhauser \& L. M. Eichinger (eds.), Deutsche Grammatik. Thema in Varationen. Festschrift für Hans-Werner Eroms zum 60. Geburtstag, 283-298. Heidelberg: Carl Winter.

Donhauser, K. \& S. Petrova. 2009. Die Rolle des Adverbs tho bei der Generalisierung von Verbzweit im Deutschen. In M. Dannerer, P. Mauser, H. Scheutz \& A. E. Weiss (eds.), Gesprochen - geschrieben - gedichtet. Variation und Transformation von Sprache, 11-24. Berlin: Erich Schmidt Verlag.

Drubig, B. H. 1992. Zur Frage der grammatischen Repräsentation thetischer und kategorischer Sätze. Linguistische Berichte, Sonderheft 4 (1991-92) 142-195.

Fleischer, J. 2006. Zur Methodologie althochdeutscher Syntaxforschung. Beiträge zur Geschichte der deutschen Sprache und Literatur 128. 25-69.

Fleischer, J., R. Hinterhölzl \& M. Solf. 2008. Zum Quellenwert des AHD-Tatian für die Syntaxforschung: Überlegungen auf der Basis von Wortstellungsphänomenen. Zeitschrift für germanistische Linguistik 36. 210-239. 
Fuss, E. 2003. On the historical core of V2 in Germanic. Nordic Journal of Linguistics 26(2). 195-231.

Fuss, E. \& C. Trips. 2009. The syntax and semantics of the temporal anaphor then in Old and Middle English. In A. Alexiadou, J. Hankamer, Th. McFadden, J. Nuger \& F. Schäfer (eds.), Advances in comparative germanic syntax, 171-196. AmsterdamPhiladelphia: John Benjamins.

Heusler, A. 1977. Altisländisches Elementarbuch. 7th ed. Heidelberg: Carl Winter.

Hinterhölzl, R. \& S. Petrova. 2010. From V1 to V2 in Older Germanic. Lingua 120(2). 315-328.

Hinterhölzl, R. \& S. Petrova. 2011. Rhetorical relations and verb placement in old High German Tatian. In C. Chiarcos, B. Claus \& M. Grabski (eds.), Salience. Multidisciplinary perspectives on its function in discourse, 173-201. Berlin: de Gruyter.

Hopper, P. 1979. Aspect and foregrounding in discourse. In T. Givón (ed.), Syntax and semantics, 213-241. San Diego: Academic Press.

Kemenade, A. v. 1987. Syntactic case and morphological case in the history of English. Dordrecht: Foris Publications.

Klein, W. 1994. Time in language. London: Routledge.

Leiss, E. 2000. Artikel und Aspekt: die grammatischen Muster von Definitheit. Berlin: de Gruyter.

Lenerz, J. 1984. Syntaktischer Wandel und Grammatiktheorie. Eine Untersuchung an Beispielen aus der Sprachgeschichte des Deutschen. Tübingen: Max Niemeyer.

Lenerz, J. 1992. Zur Theorie syntaktischen Wandels: das expletive es in der Geschichte des Deutschen. In W. Abraham (ed.), Erklärende Syntax des Deutschen, 99-136. Tübingen: Gunter Narr.

Linde, S. 2009. Aspects of word order and information structure in Old Saxon. In R. Hinterhölzl \& S. Petrova (eds.), Information structure and language change: New approaches to word order variation in Germanic, 367-389. Berlin: Mouton de Gruyter.

Masser, A. (ed.). 1994. Die lateinisch-althochdeutsche Tatianbilingue Stiftsbibliothek St Gallen Cod. 56. Göttingen: Vandenhoeck \& Ruprecht.

Masser, A. 1997. Syntaxprobleme im althochdeutschen Tatian. In Y. Desportes (ed.), Semantik der syntaktischen Beziehungen. Akten des Pariser Kolloquiums zur Erforschung des Althochdeutschen 1994, 123-140. Heidelberg: Carl Winter. 
Maurer, F. 1924. Zur Anfangsstellung des Verbs im Deutschen. In W. Horn (ed.), Beiträge zur germanischen Sprachwissenschaft. Festschrift für Otto Behaghel, 141-184. Heidelberg: Carl Winter.

Morris, R. (ed.). 1967. The Blickling homilies. 3 vols. London: Trübner.

Nygaard, M. 1966. Norrøn syntax. Oslo: H. Aschehoug \& Co.

Petrova, S. 2006. A discourse-based approach to verb placement in early WestGermanic. In S. Ishihara, M. Schmitz \& A. Schwarz (eds.), Interdisciplinary studies on Information Structure (ISIS) 5, 153-185. Potsdam: Universitätsverlag.

Petrova, S. \& M. Solf. 2008. Rhetorical relations and verb placement in the early Germanic languages: A cross-linguistic study. In C. Fabricius-Hansen \& W. Ramm (eds.), 'Subordination' versus 'coordination' in sentence and text: a cross-linguistic perspective, 329-351. Amsterdam-Philadelphia: John Benjamins.

Petrova, S., M. Solf, J. Ritz, C. Chiarchos \& A. Zeldes. 2009. Building and using a richly annotated interlinear diachronic corpus: The case of Old High German Tatian. Traitement Automatique des Langues 50(2). 47-71.

Pintzuk, S. 1996. Cliticization in Old English. In A. L. Halpern \& A. M. Zwicky (eds.), Approaching Second: Second position clitics and related phenomena, 375-409. Stanford: CSLI Publications.

Ramers, K. H. 2005. Verbstellung im Althochdeutschen. Zeitschrift für Germanistische Linguistik 33. 78-91.

Ranke, F. \& D. Hofmann. 1988. Altnordisches Elementarbuch. Einführung, Grammatik und Texte (zum Teil mit Übersetzung) und Wörterbuch. Berlin-New York: Walter de Gruyter.

Robinson, O. W. 1994. Verb-first position in the Old High German Isidor translation. Journal of English and Germanic Philology 93. 356-373.

Ruhfus, W. 1897. Die Stellung des Verbums im althochdeutschen Tatian. Dortmund: Fr. Wilh. Ruhfus.

Sankoff, D. \& S. A. Tagliamonte. 2005. Goldvarb X: A variable rule application for Macintosh and Windows. Department of Linguistics, University of Toronto. http: //individual.utoronto.ca/tagliamonte/goldvarb.htm.

Santorini, B. 1989. The generalization of the Verb-second constraint in the history of Yiddish: University of Pennsylvania dissertation. 
Sasse, H. J. 1995. "Theticity" and VS order: a case study. Sprachtypologie und Universalienforschung 48(1/2). 3-31.

Schrodt, R. 2004. Althochdeutsche Grammatik II. Syntax. Tübingen: Max Niemeyer.

Sievers, E. (ed.). 1935. Heliand. Titelauflage vermehrt um das Prager Fragment des Heliand und die Vaticanischen Fragmente von Heliand und Genesis. Halle (Saale)-Berlin: Waisenhaus.

Sigurðsson, H. A. 1990. V1 declaratives and verb raising in Icelandic. In J. Maling \& A. Zaenen (eds.), Modern Icelandic syntax, 41-69. San Diego: Academic Press.

Sornicola, R. 1995. Theticity, VS order and the interplay of syntax, semantics and pragmatics. Sprachtypologie und Universalienforschung 48(1/2). 72-83.

Tagliamonte, S. A. 2006. Analysing sociolinguistic variation. Cambridge: Cambridge University Press.

AUTHOR CONTACT INFORMATION

Svetlana Petrova

Institut für deutsche Sprache und Linguistik

Humboldt-Universität zu Berlin

Unter den Linden 9

10099 Berlin, Germany

s.petrova@hu-berlin.de 